Case Report

\title{
BEE ENVENOMATION INDUCED ACUTE RENAL FAILURE IN AN 8 YEAR OLD CHILD
}

\author{
Farzana Islam $^{1}$, Syed Dawood Md. Taimur ${ }^{2}$ and C M Shaheen Kabir ${ }^{2}$ \\ ${ }^{1}$ Department of Paediatric Nephrology, Bangabandhu Sheikh Mujib Medical University \\ ${ }^{2}$ Department of Cardiology, Ibrahim Cardiac Hospital \& Research Institute
}

\begin{abstract}
Massive envenomations by bees are capable of causing multiorgan dysfunction as a result of direct toxic effects of the large venom load received. Although all varieties of honey bee have the potential for these attacks, the Africanized honey bee (Apismellifera scutellata) is the most commonly implicated subspecies. In the United States, the Africanized strain is found primarily in the southwestern states and is known for its highly defensive behavior if disturbed. Mechanisms behind the multiorgan dysfunction produced by these mass envenomations are not clearly understood. We present a case of an 8-year-old boy who was stung by multiple bees and developed progressive upper-body swelling and systemic manifestations of mass envenomation including rhabdomyolysis, renal insufficiency, and a transient transaminase elevation.
\end{abstract}

Ibrahim Med. Coll. J. 2011; 5(1): 34-36

Key Words: environmental risk, renal failure, rhabdomyolysis, bee envenomation.

\section{Introduction}

Stinging events involving honeybees and wasps are rare; most deaths or clinically important incidents involve very few stings $(<10)$ and anaphylactic shock. However mass stinging events can prove life threatening via toxic action of the venom when injected in large amounts. ${ }^{1}$ Several types of uncommon reactions have been described including serum sickness, renal diseases, respiratory and neurological manifestations, hepatic dysfunction and delayed hypersensitivity phenomena. $^{2}$

\section{Case Report}

An 8 year old boy was stung by a swarm of bees (forest bees, Apis dorsata) two days before reporting while he was collecting fodder under a tree. He was initially treated at a district hospital and referred because he developed hematuria and decreased urine output. On examination, the patient was conscious and oriented. He had multiple sting marks all over the body ( 200), skin was infiltrated by edema and stung areas were edematous and erythematous. There was swelling of the face with pallor and dehydration. He was hemodynamically stable. No abnormality was found on systemic examination. His investigations revealed: Hemoglobin $17.5 \mathrm{~g} / \mathrm{dL}$, total WBC count $17,000 / \mathrm{cmm}$, platelets $390 \times 10^{9} / \mathrm{L}$, peripheral smear showed reticulocytosis and polychromatic RBCs. Blood urea was $139 \mathrm{mg} / \mathrm{dL}$, S. creatinine $7.8 \mathrm{mg} / \mathrm{dL}$ (normal 0.5 1.5), sodium $125 \mathrm{meq} / \mathrm{L}$, potassium $5.12 \mathrm{meq} / \mathrm{L}$, calcium $8.3 \mathrm{mg} / \mathrm{dL}$, phosphorous $8 \mathrm{mg} / \mathrm{dL}$, uric acid $7.5 \mathrm{mg} /$ $\mathrm{dL}$, protein $5.2 \mathrm{gm} / \mathrm{dL}$, albumin $3.5 \mathrm{gm} / \mathrm{dL}$, ASO titre -554IU/ml, C3-1.04g/l, HBs Ag-negative, bilirubin 1.5 $\mathrm{mg} / \mathrm{dL}$ (conjugated 0 ), aspartate aminotransferase (AST) $121 \mathrm{IU} / \mathrm{L}$, alanine aminotransferase (ALT) 149 $\mathrm{IU} / \mathrm{L}$, alkaline phosphatase $112 \mathrm{U} / \mathrm{L}$, lactate dehydrogenase (LDH) 2740 U/L (normal 240-480), creatine phosphokinase (CPK) $2888 \mathrm{U} / \mathrm{L}$ (normal < 167).

Arterial blood gas (ABG) revealed $\mathrm{pH} 7.35, \mathrm{paO}_{2} 80$ $\mathrm{mmHg}, \mathrm{paCO}_{2} 34, \mathrm{HCO}_{3} 18 \mathrm{meq} / \mathrm{L}$. Urine examination: color was reddish, appearance was initially clear then hazy, albumin ++ , pus cells $2-6 /$

Address for Correspondence:

Dr. Farzana Islam, Department of Paediatric Nephrology, Block: D, $3^{\text {rd }}$ Floor, Bangabandhu Sheikh Mujib Medical University. Shahbagh, Dhaka-1000, Bangladesh, Mobile: +8801718011237, Email:dr.farzanaislamsilvi@yahoo.com 

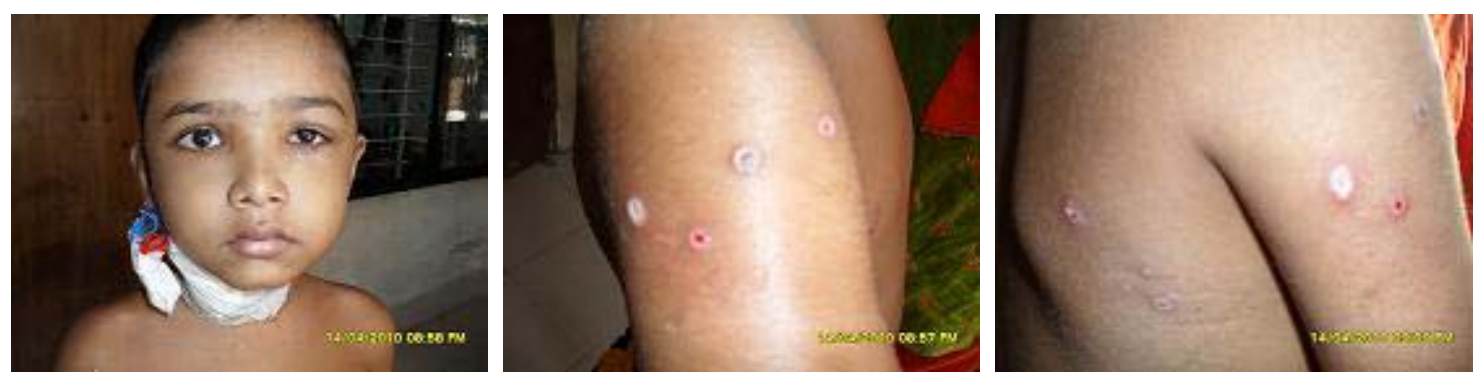

hpf, RBCs 35-45/hpf, urine hemoglobin + , urine culture - sterile.

Laboratory findings were consistent with intravascular hemolysis, rhabdomyolysis, acute renal failure and hepatic dysfunction. Patient was treated with fluid restriction, diuretics, antibiotics, steroids, antihistamins and sodium bicarbonate. Ultimately he needed four sessions of hemodialysis after which he gradually improved and renal function returned to near normal by day fifteen.

\section{Discussion}

This case demonstrates that multiple bee stings may cause rhabdomyolysis and hemolysis with consequent ATN. Components of venom include toxic surfaceactive polypeptides (mellitin and apamin), enzymes (phospholipase $\mathrm{A}_{2}$ and hyaluronidase) and low molecular weight agents (histamine and aminoacids). Mellitin and phospholipase are important components causing rhabdomyolysis following a toxic action on striated muscles which also acts on the red cell membrane and provokes hemolysis. ${ }^{3}$ The elevated levels of enzymes CPK and aspartate-aminotransferase suggest the existence of rhabdomyolysis and hemolysis is suggested by anemia, unconjugated hyperbilirubinemia, reticulocytosis, increased serum $\mathrm{LDH}$ and hemoglobinuria. ${ }^{3}$

Rhabdomyolysis and hemolysis can induce ARF, particularly in hypovolemic or acidotic individuals. It has been postulated that myoglobin and hemoglobin released from muscle or red blood cells cause ARF by toxic effects on tubule epithelial cells or by inducing intratubular cast formation. Hypovolemia or acidosis may contribute to pathogenesis of ARF in this setting by promoting intratubular cast formation. In addition, both hemoglobin and myoglobin are potent inhibitors of nitric oxide bioactivity and may trigger intrarenal vasoconstriction and ischemia in patients with borderline renal hypoperfusion. ${ }^{4}$

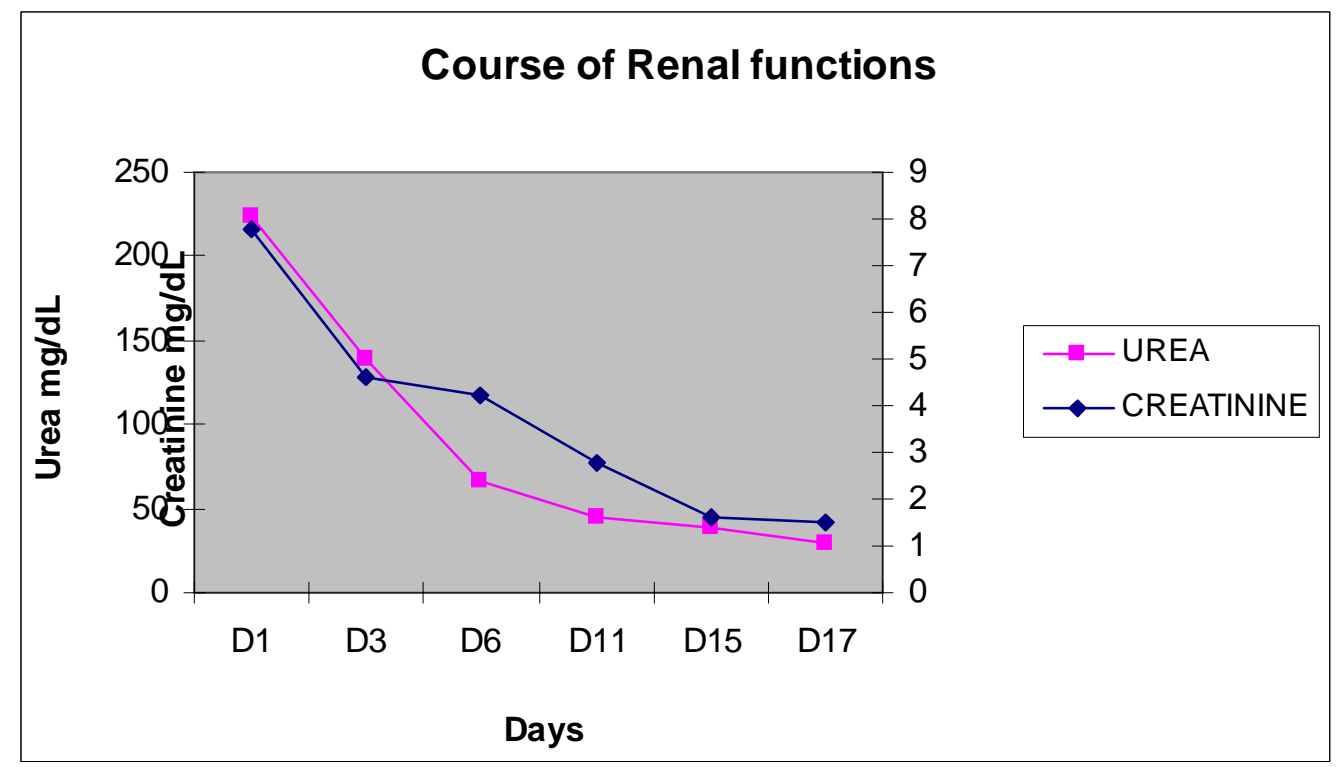


The mortality associated with Africanized honeybee attacks is primarily the result only of the number of the number of stings. ${ }^{5}$ A number of about 500 stings have been considered necessary to cause death by direct toxicity, but as few as 30-50 stings have proved fatal in children. ${ }^{3}$ Our patient had about 200 stings and survived with complete renal recovery. The primary therapeutic goal is to prevent the factors that cause ARF, i.e. volume depletion, tubular obstruction, aciduria and free radical release. Patients are administered saline for intravascular volume expansion and sodium bicarbonate for urine alkalization (to urine $\mathrm{pH}$ level above 7). The ideal fluid regimen for patients with rhabdomyolysis consists of half isotonic saline $(0.45 \%$, or $77 \mathrm{mmol} / \mathrm{L}$ sodium), to which $75 \mathrm{mmol} / \mathrm{L}$ of sodium bicarbonate is added. Once overt renal failure has developed, the only reliable therapeutic modality is extracorporeal blood purification. ${ }^{4}$ Exchange transfusion or plasmaphresis has been found useful because it acts through a direct effect of reduction of the massive circulating venom or removal of the circulating mediators of inflammation caused by the venom itself. 3,6

\section{References}

1. Vetter RS, Visscher PK, Camazine S. Mass envenomations by honey bees and wasps. West J Med 1999; 170: 223-227.

2. Franca FO, Benvenuti LA, Fan HW, Dos Santos DR, Hain SH, Picchi-Martins FR, et al. Severe and fatal mass attacks by 'killer' bees (Africanized honey beesApis mellifera scutellata) in Brazil: clinicopathological studies with measurement of serum venom concentrations. Q J Med 1994; 87: 269-282.

3. Bresolin NL, Carvalho LC, Goes EC, Fernandes R, Barotto AM. Acute renal failure following massive attack by Africanized bee stings. Pediatr Nephrol 2002; 17: 625-627.

4. Zager RA. Rhabdomyolysis and myohemoglob -inuric acute renal failure. Kidney Int 1996; 49: 314-326.

5. Schumacher MJ, Schmidt JO, Egen NB. Lethality of "killer" bee stings. Nature 1989; 337: 413.

6. Beccari M. Dialysis or plasmapheresis for acute renal failure due to Africanized honeybee stings. Arch Intern Med 1999; 159: 1255-1256. 